\title{
Pengenalan Angka Menggunakan Permainan Puzzle dan Pengaruhnya Terhadap Perkembangan Emosi dan Kemampuan Motorik Halus Anak Usia Dini di Play Group Se-Kecamatan Sumbersari Kabupaten Jember
}

\author{
Panca Oktavia Abristiana ${ }^{1)}$, Anik Kristanti ${ }^{2)}$, Afifiy Aisyatul W' \\ ${ }^{1)}$ IKIP PGRI Jember \\ ${ }^{2)}$ KB Nurus Shibyan Bangsalsari Jember \\ ${ }^{3)}$ TK Pertiwi Mayang Jember \\ Email : Pancaoctavia64@gmail.com, anikkristan@gmail.com, \\ afifiyaisya@gmail.com
}

\begin{abstract}
The puzzle game is a simple medium that is played by means of loading and unloading. Some of the benefits that can be obtained from puzzle games are the development of emotions and fine motor skills in early childhood. The development of emotions and fine motor skills of early childhood is an important factor to support children's confidence both for the school and home environment. Preliminary observations show that of the 64 Play Groups in Sumbersari District, it shows that the use of puzzle media is not optimal for both school and home activities. To improve emotional development and fine motor skills of early childhood needs to be optimized in puzzle games. The formulation of the problems in this study includes: "Is the effect of puzzle games together on the emotional development and fine motoric abilities of young children in the Play Group of Sumbersari District, Jember Regency in the Academic Year 2018-2019 ?. The subjects of this study were 72 students from 64 schools in the Sumbersari District Play Group, using observations, questionnaires, documentation, and interviews as data collection techniques. The results showed an increase in emotional development and fine motor skills of early childhood by applying puzzle games. Based on the results of this study, suggestions are given to researchers for principals, mentors, and parents in order to be able to apply puzzle games both to improve children's emotional development and fine motor skills.
\end{abstract}

Keywords : Puzzle, Emotional Development, Fine Motor Skills 


\begin{abstract}
ABSTRAK
Permainan puzzle merupakan media sederhana yang dimainkan dengan cara bongkar pasang. Beberapa manfaat yang dapat diperoleh dari permainan puzzle adalah perkembangan emosi dan kemampuan motorik halus terhadap anak usia dini. Perkembangan emosi dan kemampuan motorik halus anak usia dini merupakan faktor penting untuk menunjang rasa percaya diri anak baik untuk lingkungan sekolah maupun rumah. Hasil observasi awal menunjukkan bahwa dari 64 Play Group yang ada di Kecamatan Sumbersari menunjukkan bahwa kurang maksimalnya penggunaan media puzzle baik untuk kegiatan di sekolah maupun dirumah. Untuk meningkatkan perkembangan emosi dan kemampuan motorik halus anak usia dini perlu dioptimalkan dalam permainan puzzle. Rumusan masalah dalam penelitian ini meliputi: "Adakah pengaruh permainan puzzle secara bersama-sama terhadap perkembangan emosi dan kemampuan motoric halus anak usia dini di Play Group Kecamatan Sumbersari Kabupaten Jember Tahun Ajaran 2018-2019?. Subjek penelitian ini adalah 72 siswa dari 64 sekolah di Play Group Kecamatan Sumbersari, dengan menggunakan observasi, angket, dokumentasi dan wawancara sebagai teknik pengumpulan datanya. Hasil penelitian menunjukkan adanya peningkatan terhadap perkembangan emosi dan kemampuan motoric halus anak usia dini dengan menerapkan permainan puzzle. Berdasarkan hasil penelitian ini, saran yang diberikan kepada peneliti bagi kepala sekolah, pembimbing maupun orang tua agar dapat menerapkan permainan puzzle baik untuk meningkatkan perkembangan emosi dan kemampuan motorik halus anak.
\end{abstract}

Kata Kunci : Puzzle, Perkembangan Emosi, Kemampuan Motorik Halus

\title{
PENDAHULUAN
}

Bermain merupakan bagian terpenting perkembangan emosional, sosial, fisik, dan motorik seorang anak. Bermain adalah cara setiap anak untuk belajar tentang tubuh dan dunianya. Maka bagi anak usia dini, bermain sama dengan belajar. Melalui mainan yang digunakan untuk bermain, anak dapat melatih koordinasi antara mata dan tangannya yang masih belum terlalu baik, pendek kata apapun permainan yang dimainkan anak akan mempelajari banyak hal baru dari aktifitas bermainnya. Dengan anak menggunakan permainan yang sesuai dengan usia maka ada beberapa manfaat yang dapat diperoleh oleh anak misalnya, dapat melatih kemampuan motorik anak. Stimulasi untuk motorik halus diperoleh saat anak menjumput mainannya, meraba, memegang dengan kelima jarinya dan sebagainya. Dan manfaat lain yang dapat dipeoleh yaitu untuk melatih konsentrasi. Permainan yang edukatif dirancang untuk menggali kemampuan anak, termasuk kemampuannya dalam berkonsentrasi. Misalnnya saat menyusun puzzle, anak dituntut untuk fokus pada gambar atau bentuk 
yang ada didepannya, anak tidak berlarian atau dituntut untuk fokus pada gambar atau bentuk yang ada didepannya, anak tidak berlarian atau melakukan aktifitas lain sehingga konsentrasinya bisa lebih terkendali (Titin S. Pramono, 2010 : 35). Melalui bermain anak dapat melewati tahap-tahap perkembangan baik untuk mengoptimalkan perkembangan emosi dan kemampuan motorik halus anak melalui Alat Permainan Edukatif (APE), yang salah satunya adalah Puzzle.

Melalui permainan puzzle pekembangan emosi maupun kemamuan motorik halus anak usia dini dapat berkembang dengan sangat baik. Karena dengan permainan puzzle anak menggunakan semua kemamuan yang ada dalam diri anak yang kadang tidak diketahui secara langsung oleh orang tua maupun oleh pendidik. Dengan berkembangnya emosi maupun kemampuan moorik halus anak dapat menambah rasa percaya diri anak maupun eksistensinya dalam pergaulan dirumah maupun lingkungan sekolah.

Berdasaakan latar belakang di atas, maka peneliti tertarik untuk memfokuskan dan mengangkat judul mengenai Pengaruh Permainan Puzzle terhadap Perkembangan Emosi dan Kemampuan Motorik Halus Anak Usia Dini di Play GroupKecamatan Sumbersari Kabupaten Jember Semester Genap Tahun Ajaran 20152016.

Berdasarkan pada latar belakang masalah, maka tujuan Penelitian adalah (1) Ingin mengetahui ada tidaknya pengaruh permainan puzzle terhadap perkembangan emosi anak usia dini, (2) Ingin mengetahui ada tidaknya pengaruh permainan puzzle terhadap kemampuan motorik halus anak usia dini, dan (3) Ingin mengetahui ada tidaknya pengaruh permainan puzzle terhadap perkembangan emosi dan kemampuan motorik halus secara bersama-sama pada anak usia dini di Play Group di Kecamatan Sumbesari Kabupaten Jember Semester Genap Tahun Ajaran 2018-2019.

Menurut Kamus Besar Bahasa Indonesia (2003 : 352), puzzle adalah "tekateki”. Menurut Hamalik (1980 : 57), gambar adalah sesuatu yang mewujudkan secara visual dalam bentuk dua dimensi sebagai curahan perasaan dan pikiran. Media puzzle merupakan media gambar yang termasuk dalam media visual karena hanya dapat dicerna melalui indera penglihatan saja.

Puzzle merupakan permainan yang membutuhkan kesabaran dan ketekunan anak dalam merangkainya, puzzle merupakan kepingan tipis yang terdiri dari 2-3 
bahkan 4-6 potong yang terbuat dari kayu atau lempeng karton. Dengan terbiasa bermain puzzle, lambat laun mental anak juga akan terbiasa untuk bersikap tenang, tekun, dan sadar dalam menyelesaikan sesuatu. Kepuasaan yang didapat saat anak menyelesaikan puzzle pun merupakan salah satu pembangkit motifasi anak untuk menemukan hal-hal baru.

Dunia anak adalah dunia bermain dan belajar. Anak-anak lebih ,mudah menangkap ilmu kalau diberikan lewat permainan, jadi anak-anak bisa sekaligus bermain tetap belajar. Dalam dunia anak-anak terdapat berbagai jenis permainan, salah satu jenis permainan yang bermanfaat bagi anak dan bersifat edukatif adalah puzzle. Puzzle merupakan permainan yang membutuhkan kesabaran dan ketekunan anak dalam merangkainya

Beberapa manfaat puzzle menurut Mutiah sebagai media bermain antara lain:

1. Meningkatkan kemampuan kognitif anak

2. Meningkatkan keterampilan motorik halus

3. Melatih kemampuan nalar dan daya ingat dan konsentrasi

4. Melatih kesabaran

5. Pengetahuan melalui puzzle

6. Meningkatkan keterampilan sosial

Menurut Muzamil (2010 : 145) menyatakan beberapa bentukpuzzle, antara lain:

1. Puzzle Rakitan (Construction Puzzle)

2. Puzzle Batang (Stick)

3. Puzzle lantai

4. Puzzle angka

5. Puzzle Transportasi

6. Puzzle Logika

Cara bermain puzzle tidaklah sulit. Biasanya anak-anak langsung mengenali permainan ini dan langsung bisa memainkannya. Puzzle yang digunakan dalam penelitian menggunakan puzzle logika yang bergambar manusia dengan jumlah kepingan yang terdiri dari 10 keping tiap puzzlenya. Adapun langkah-langkah dalam memainkan permainan puzzle yaitu sebagai berikut (Yulianty, 2013 : 45) : 1. Lepaskan kepingan puzzle dari papannya, 2. Acak kepingan puzzle tersebut, 3. Mintalah anak 
memasangkan kembali, 4. Berikan tantangan kepada anak untuk melakukannya dengan cepat. Bisa dengan hitungan angka 1 sampai dengan 10, stopwacth dan lainlain.

Menurut Santrock (2007 : 6), medefiniskan emosi tidaklah semudah menyatakan bahwa seseorang sedang berada dalam keadaan emosi tertentu. Untuk memudahkan kita, kita akan mendefinisikan emosi sebagai perasaaan atau afeksi yang timbul ketika seseorang sedang berada dalam suatu keadaan atau suatu interaksi yang dianggap penting olehnya, terutama well-being dirinya. Emosi diwakili oleh perilaku yang mengekspresikan kenyamanan atau ketidaknyamanan terhadap keadaan atau interaksi yang sedang dialami. Emosi juga bisa berbentuk sesuatu yang spesifik seperti rasa senang, takut, marah dan seterusnya, tergantung dari interaksi yang dialami, emosi juga dibedakan dari intensitasnya. Sebagai contoh, seorang bayi bisa menunjukkan ketakutan yang luar biasa pada situais tertentu.

Kondisi yang mempengaruhi perkembangan emosi menurut Hurlock (1978 : 213), antara lain sebagai berikut:

1. Peran Pematangan

Perkembangan intelektual menghasilkan kemampuan untuk memahami makna yang sebelumnya tidak dimengerti, memperhatikan satu rangsangan dalam jangka waktu yang lebih lama, dan memutuskan ketegangan emosi pada satu objek. Demikian pula kemampuan mengingat dan menduga mempengaruhi reaksi emosional. Dengan demikian, anak-anak menjadi reaktif terhadap rangsangan yang tadinya tidak mempengaruhi mereka pada usia yang lebih muda.

2. Peran Belajar

Lima jenis kegiatan belajar yang menunjang pola perkembangan emosi pada anakanak, diantara adalah sebagai berikut : belajar secara coba dan ralat, belajar dengan meniru, belajar dengan cara mempersamakan diri, belajar dengan pengkondisian, dan pelatihan.

Anak yang lebih muda mengalami hampir semua emosi yang secara normal dialami oleh orang dewasa. namun rangsangan yang membangkitkan emosi dan cara anak mengungkapkan emosi sangat berbeda. Pola-pola umumnya pada awalnya masa kanak-kanak diantaranya sebagai berikut : (Hurlock, 1980 : 116) :

1. Amarah 
2. Takut

3. Cemburu

4. Ingin tahu

5. Iri hati

6. Gembira

7. Sedih

8. Kasih sayang

Emosi pada anak-anak mengalami perbedaan satu anak dengan anak yang lainnya. Perbedaan ini terjadi karena adanya pengaruh yang menyebabkan anak untuk beraksi dengan emosi yang sangat kuat dan adanya reaksi anak dengan emosi yang lemah. Diantara faktor yang mempengaruhi perbedaan tersebut adalah:

1. Kecerdasan, perkembangan kecerdasan anak sangat mempengaruhi reaksi emosi yang ditimbulkan. Rasa keingintahuan anak sangat menekan kuat lemahnya emsoi yang ditimbulkan. Anak yang mempunyai kecerdasan dan keingintahuan yang baik, ternyata lebih aktif untuk merespon rangsangan untuk membangkitkan emosinya, dibandingkan anak yang tidak mempunyai rasa keingintahuan dan kurang kecerdasan.

2. Jenis kelamin, umumnya tidak terjadi suatu perbedaan antara anak laki-laki dan perempuan dalam proses perkembangan emosi pada masa anak-anak. Hanya karena pengkondisian anak sehingga banyak anak laki-laki yang menggunakan secara aktif emosinya seperti ledakan emosi, marah, lebih ditunjukkan pada anak laki-laki dibandingkan anak perempuan. Sebaliknya rasa takut, cemburu dan kasih sayang merupakan tempat emosi yang sesuai bagi anak perempuan daripada anak laki-laki.

3. Lingkungan keluarga, besar kecilnya sangat mempengaruhi timbulnya reaksi emosi pada anak yaitu keluarga yang terdiri dari banyak anak dengan sedikit anak. Keluarga yang sedikit anaknya akan sangat berkurang persaingannya, dibandingkan dengan keluarga besar yang banyak anak lebih sering menimbulkan persaingan, yaitu persaingan untuk mendapatkan sesuatu, baik kasih kasih maupun benbentuk benda.

4. Lingkungan sosial, lebih banyak anakbersosialisasi dengan teman-temannya lebih mampu untuk mereaksi emosinya dengan anak yang tidak dapat mendapatkan 
kesempatan untuk bersosialisasi. Reaksi emosi yang dipengaruhi oleh lingkungan sma.osial akan lebih banyak menimbulkan rasa solidaritas yang tinggi, persaudaraan yang tinggi, persaudaraa, simpati, kasih sayang, rasa tanggung jawab, rasa tentram, optimis dan lain sebagainya.

Perkembangan motorik berarti perkembangan pengendalian gerakan jasmaniah melalui kegiatan pusat syaraf, urat syaraf dan otot yang terkoordinasi. Pengendalian tersebut berasal dari perkemabngan refleksi dan kegiatan massa yang ada pada waktu lahir. Sebelum perkembangan tersebut terjadi, anak akan tetap tidak berdaya. Akan tetapi ketidak berdayaannya tersebut berubah secara cepat.

Yudha dan Rudyanto (2005 : 118), menyatakan bahwa motorik halus adalah kemampuan anak beraktifitas dengan menggunakan otot halus (kecil) seperti menulis, meremas, menggambar, menyusun balok, dan memasukkan kelereng. Demikian pula menurut Sujiono (2008 : 125) menyatakan bahwa motorik halus adalah gerakan yang hanya melibatkan bagian-bagian tertentu saja yang dilakukan oleh otot-otot kecil, seperti keterampilan menggunakan jari jemari tangan dan gerakan pergelangan yang tepat. Oleh karena itu gerakan itu tidak terlalu membutuhkan tenaga, namun gerakan ini membutuhkan koordinasi mata dan tangan yang cermat. Semakin baiknya gerakan motorik halus anak membuat anak dapat berkreasi, seperti menggunting kertas, menggambar, mewarnai, serta menganyam. Namun tidak semua anak memiliki kematangan untuk menguasai kemampuan ini pada tahap yang sama.

Gerakan motorik halus adalah gerakan hanya melibatkan bagian-bagian tubuh tertentu saja dilakukan oleh otot-otot kecil, seperti keterampilan menggunakan jari jemari tangan dan gerakan pergelangan tangan yang tepat. Gerakan ini membutuhkan koordinasi mata dan tangan yang cermat. Gerakan motorik halus yang terlihat saat anak usia prasekolah, antara lain adalah anak mulai menyikat gigi, menyisir, memakai sepatu, dan sebagainya. Perkembangan merupakn proses memperoleh keterampilan dan pola gerakan yang dapat dilakukan anak. Misalnya dalam kemampuan motorik kasar anak belajar menggerakkan seluruh atau sebagian besar anggota tubuh, sedangkan dalam motorik halus anak belajar ketepatan mata dan tangan. Anak juga belajar menggerakkan pergerakan tangan agar lentur dan anak belajar berkreasi dan berimajinasi. Semakin baiknya gerakan motorik halus anak membuat anak dapat berkreasi, seperti menggunting kertas, menganyam kertas, tapi 
tidak semua anak memiliki kematangan untuk menguasai kemampuan pada tahap yang sama. Dalam melakukan gerakan motorik halus anak juga memerlukan dukungan keterampilan fisik serta kematangan mental.

Beberapa keterampilan tangan yang penting bagi anak untuk dikembangkan (Kurniasih, $2009:$ 32), diantarnya :

1. Mampu melengkungkan telapak tangan membentuk cekungan (palmar arching)

2. Menggunakan jari telunjuk dan jempol untuk memegang suatu benda

3. Menggunakan jari tengah dan jari manis untuk kestabilan tangan (hand side separation)

4. Membuat bentuk lengkung dengan jempol dan telunjuk (open web space)

Aktifitas-aktifitas untuk mengembangkan keterampilan motorik halus, antara lain:

1. Vertical Surfaces (permukaan vertikal)

Latihan pada permukaan vertikal membantu mengembangkan otot-otot kecil pada tangan dan pergelangan sekaligus otot-otot yang lebih besar (otot-otot besar) pada lengan dan punggung.

2. Merobek dan meremas

Merobek dan meremas kertas membantu mengembangkan otot halus pada tangan yang juga digunakan untuk menulis.

3. In-Hand Manipulation (manupilasi tangan)

Memerlukan penggunaan semua kemampuan motorik halus yang dituliskan diatas. Kita semua bergantung pada manipulasi tangan sepanjang hari. Contohnya ketika kita memasukkan uang logam ke dalam celengan. Kita memegang semua uang logam di dalamsatu telapak tangan (palmar arching). Sementara itu kita memasukkan uang logam ke dalam celengan, kita memindahkan koin ke ujung jempol dan telunjuk satu persatu (web space), sementara pada saat yang sama menjaga sisa koinnya tetap aman di dalam genggaman telapak tangan dengan menggunakan jari-jari lain (hand side separation)

4. Menggambar dan mewarnai

Seringkali anak-anak menggunakan pensil, crayon, dan maker sebelum tangantangan mereka siap untuk alat-alat tulis tersebut. Hal ini bisa menyebabkan pembelajaran memegang pensil dengan cara yang tidak efisien, yang pada 
akhirnya menjadi masalah. Untuk menyemangati anak mengembangkan pola memegang yang benar, berilah anak alat-alat tulis yang bisa membantu mengembangkan keterampilan motorik halus. Misalnya crayon yang pendek (tidak lebih dari $5 \mathrm{~cm}$ panjangnya), akan membuat anak mennggunakan keterampilan tangannya daripada seluruh tangan.

5. Menulis

Sejak dini anak sudah dikenalkan pada kegiatan menulis dengan menggunakan alat tulis, baik crayon, spidol, cat air, dan lainnya. Hal ini akan membantu anak untuk menumbuhkan minat pada kegiatan menulis, dimulai dengan aktifitas menguhubungkan titik-titik, menyediakan media tulisan dengan buku halus kasar yang tersedia di toko buku, berlatih sesering mungkin untuk belajar menulis, dimulai dengan menulis namanya sendiri secara berulang-ulang.

\section{METODE PENELITIAN}

Lokasi penelitian dilakukan di Play Group di Kecamatan Sumbersari Jember dengan populasi sebesar 64 sekolah dan diambil 8 sampel sekolah untuk dilakukannya penelitian. Teknik sampel yang digunakan menggunakan teknik ramdom sampoling tekni untuk dengan cara menuliskan semua nama sekolah yang menjadi populasi penelitian lalu mengacaknya dan mengambil nama sekolah yang akan digunakan sampel dengan cara diundi.

Metode pengambilan responden dalam penelitian ini adalah dengan teknik population Research yang diartikan sebagai wilayah generalisasi yang terdiri atas : objek/subjek yang mempunyai kualitas dan karakteristik tertentu yang diterapkan oleh peneliti untuk dipelajari dan kemudian ditarik kesimpulan (Sugiyono, 2006 : 110). Sedangkan menurut Burhan (2000 : 40) adalah keseluruhan (universum) dari objek penelitian yang berupa manusia, hewan, tumbuh-tumbuhan, udara, gejala, nilai, peristiwa, sikap hidup, dan sebagainya sehingga objek-objek ini dapat menjadi sumber data penelitian.

Metode pengumpulan data adalah cara yang dapat digunakan oleh peneliti untuk mengumpulkan data. Dalam penelitian ini menggunakan metode pengumpulan data diantaranya (Abdurahman, dkk, $2011: 38$ ) :

1. Observasi 
Merupakan salah satu teknik pengumpulan data dimana peneliti mengadakan pengamatan dan pencatatan secara sistematis terhadap objek yang diteliti, baik dalam situasi buatan yang secara khusus diadakan (laboratorium) maupun dalam situasi alamiah atau sebenarnya (lapangan).

2. Angket

Atau yang juga dikenal sebagai kuesioner merupakan salah satu teknik pengumpulan data dalam bentuk pengajuan pertanyaan tertulis melalui sebuah daftar pertanyaan yang sudah dipersiapkan sebelumnya, dan harus diisi oleh responden.

3. Dokumentas

Merupakan catatan usang yang sudah berlalu baik berbemntuk tulisan, gambar, atau karya monumental seseorang (Sugiyono,. $2005: 82$ ).

4. Wawancara

Merupakan salah satu teknik pengumpulan data yang dilakukan dengan cara mengadakan tanya jawab tentang keadaan sekolah maupun peserta didik, baik secara langsung maupun tidak langsung secara bertatap muka dengan sumber data (responden).

Metode analisis data yang digunakan dalam penelitian ini menggunakan analisis varians (anava) dengan desain dua jalan dan analisis deskriptif. Menurut Arikunto (2009 : 401), sebagai teknik analisis varians memiliki banyak kegunaan, yaitu: 1. Anak dapat digunakan untuk menentukan apakah rerata nilai dari dua atau lebih sampel berbeda secara signifikan atau tidak, 2. Perhitungan anava menghasilkan harga $\mathrm{F}$ yang signifikan menunjukkan kepada peneliti bahwa sampel yang diteliti berasal dari populasi yang berbeda, walaupun anava tidak dapat menunjukkan secara rinci yang manakah diantara rerata nilai dari sampel-sampel tersebut yang berbeda secara signifikan satu sama lain, 3. Anava dapat digunakan untuk menganalisis data yang dihasilakn dengan desain faktorial jamak, sehingga dapat diguinakan untuk menganalisis data yang dihasilkan dengan desain faktorial jamak, sehingga dapat mengetahui antar variabel manakah yang memamng mempunyai perbedaan secara signifikan, dan variabel-variabel manakah yang berinteraksi satu sama lain, 4. Anava mampu mengetes signifikasi dari kecenderungan yang dihipotesiskan yang hasilnya adalah analisis kecenderungan. 
Uji validitas menurut Arikunto (2009 : 167) secara mendasar validitas adalah keadaan yang menggambarkan tingkat intrum,en yang bersangkutan mampu mengukur apa yang akan diukur. Sedangkan pendapat Sukardi (2008: 123), yang dimaksud dengan validitas isi adalah derajat dimana sebuah tes mengukur cakupan substansi yang ingin diukur. Untuk mendapatkan validitas isi memerlukan dua aspek penting, yaitu valid isi dan valid teknik samplingnya. Valid isi mencakup khususnya hal-hal yang berkaitan dengan apakah item-item itu menggambarkan pengukuran dalam cakupan yang ingin diukur. Sedangkan validitas sampling pada umumnya berkaitan dengan bagaimanakah baiknya suatu sampel tes merepresentasikan total cakupan isi.

Dasar pengambilan keputusannya adalah sebagai berikut (Raharjo, 2014):

1. Jika nilai r-hitung lebih besar dari nilai t-tabel, maka tes tersebut dinyatakan valid

2. Jika nilai r-hitung lebih kecil dari nilai t-tabel, maka tes tersebut dinyatakan tidak valid.

Ada tiga teknik untuk menguji reliabilitas instrumen tersebut, diantaranya (Arikunto, $2009: 168)$ :

1. Terknik paralel disebut juga dengan teknik double test double trial. Jika peneliti memilih teknik tes paralel untuk menguji reliabilias instrumen maka sejak awal peneliti sudah menyusun dua perangkat instrumen yang paralel, yaitu dua buah instrumen yang disusun berdasarkan satu kisi-kisi.

2. Teknik ulangan disebut juga teknik single test double trial. Dengan menggunakan teknik pertama dengan sendirinya peneliti harus menyusun dua perangkat instrument..

3. Teknik belah dua disebut juga dengan single test single trial. Dengan teknik pertama peneliti harus menyiapkan dua perangkat instrumen dan harus mengujicobakan dua kali. Dengan teknik kedua peneliti hanya memerlukan seperangkat insrumen saja tetapi diujicobakan dua kali.

Dasar pengambilan keputusannya adalah sebagai berikut (Raharjo, 2014):

1. jika nilai Alpha lebih besar dari r-tabel maka item-item tes yang digunakan dinyatakan reliabel atau konsisten

2. jika nilai Alpha lebih kecil dari r-tabel maka item-item tes yang digunakan dinyatakan tidak reliabel atau tidak konsisten. 
Uji normalitas digunakan untuk mengetahui apakah data sampel berasal dari populasi yang berdistribusi normal. Untuk menguji normalitas data, digunakan SPSS 16 dengan langkah-langkah sebagai berikut:

a) Merumuskan hipotesis pengujian normalitas data adalah sebagai berikut:

Ho: data sampel berasal dari populasi yang berdistribusi normal

Ha: data sampel berasal dari populasi yang tidak berdistribusi normal

b) Menguji normalitas data menggunakan uji Kolmogorov-Smirnov Test

c) Melihat nilai signifikansi pada kolom Kolmogorov-Smirnov, dengan menggunakan taraf signifikansi $5 \%(\alpha=0,05)$, kriteria pengambilan keputusannya adalah sebagai berikut:

Jika nilai signifikansi > 0,05, maka Ho diterima

Jika nilai signifikansi $<0,05$, maka Ho ditolak.

Jika kedua data kelas berdistribusi normal, maka dilanjutkan dengan pengujian homogenitas data dengan menggunakan uji Levene pada SPSS 20. Uji homogenitas data digunakan untuk menguji homogen atau tidaknya data sampel yang diambil dari populasi yang sama. Untuk menganalisis homogenitas data, digunakan uji Levene's test dalam SPSS 16, dengan langkah-langkah sebagai berikut:

a) Merumuskan hipotesis pengujian homogenitas data sebagai berikut:

Ho: data sampel berasal dari populasi yang homogen

Ha: data sampel berasal dari populasi yang tidak homogen

b) Menghitung uji homogenitas data dengan menggunakan rumus Levene's test dalam SPSS 16

c) Melihat nilai signifikansi pada uji Levene's test, dengan menggunakan taraf signifikansi $5 \%(\alpha=0,05)$, kriteria pengambilan keputusannya adalah sebagai berikut:

Jika nilai signifikansi $>0,05$, maka Ho diterima

Jika nilai signifikansi $<0,05$, maka Ho ditolak.

\section{HASIL DAN PEMBAHASAN}

Kelas uji diambil sebanyak 35 siswa dan untuk kelas eksperimen terdiri dari 72 siswa yang diikutkan dalam penelitian ini. Untuk menentukan kelas uji dan eksperimen dipilih kelas yang homogen dan mempunyai tingkat umur yang sama di 8 
sekolah yang dijadikan sebagai kelas eksperimen. Uji validitas dan reliabilitas diperlukan untuk menjamin bahwa angket (sebelum dan sesudah kegiatan) yang dipakai dalam penelitian ini telah memenuhi kelayakan.Formulasi uji validitas untuk skala soal tes menggunakan formulasi korelasi point biserial karena data yang dihasilkan berbentuk dikotomi (benar-salah, dimana jawaban benar diberi skor 1, dan jawaban salah diberi skor 0) (Ariyanto, 2015 : 44).Sedangakan uji reliabilitas dibutuhkan agar instrumen yang digunakan memiliki tingkat keajegan yang dapat dipercaya.

Tabel 1. Hasil Uji Reliabilitas Instrumen

\begin{tabular}{|l|c|c|c|c|c|c|}
\hline \multicolumn{3}{|c|}{ Nilai Cronback's Alpha } & \multicolumn{3}{c|}{ Nilai r-tabel (signifikasi 5\%) } & \multirow{2}{*}{ Kesimpulan } \\
\hline Puzzle & Emosi & Motorik & Puszle & Emosi & Motorik & \\
& & Halus & & & Halus & \\
\hline 0.994 & 0.992 & 0.996 & 0.235 & 0.235 & 0.235 & Reliable \\
& & & & & & \\
\hline
\end{tabular}

Kriteria pengambilan keputusan uji reliable soal adalah item soal reliable bila nilai $r$ hitung > nilai r-tabel. Nilai r-tabel yang digunakan adalah taraf signifikasi 5\%, diperoleh nilai 0.235 . Item soal dikatakan reliabel bila nilai Cronbach`s Alpha lebih besar dari nilai r-tabel. Namun bila nilai Cronbach`s Alpha lebih kecil dari nilai r-tabel maka item soal yang tidak reliabel tersebut harus diperbaiki atau dibuang.

Metode penelitian yang digunakan dalam penelitian ini adalah metode analisis data yang digunakan dalam peneltian ini menggunakan analisis varians (anava) dengan desain dua jalan dan analisis deskriptif.

Berdasarkan uji Kolmogorov-Smirnov diperoleh hasil untuk sekolah kelas uji dan kelas eksperimen. Untuk lebih jelasnya bila dilihat pada Tabel 2 dibawah ini :

Tabel 2. Hasil Uji Normalitas

\begin{tabular}{|c|c|c|c|c|c|c|c|}
\hline \multirow[b]{2}{*}{ Perlakuan } & \multicolumn{3}{|c|}{ Nilai Lavene Statistic (pretest) } & \multicolumn{3}{|c|}{ Nilai Sig. } & \multirow[b]{2}{*}{ Kesimpulan } \\
\hline & Puzzle & Emosi & $\begin{array}{l}\text { Motorik } \\
\text { halus }\end{array}$ & Puczle & Emosi & $\begin{array}{l}\text { Motorik } \\
\text { Halus }\end{array}$ & \\
\hline Sebelum & 0.770 & 0.772 & 0.775 & 0.582 & 0.584 & 0.560 & Homogen \\
\hline Sesudah & 2.059 & 2.108 & 2.079 & 0.306 & 0.310 & 0.316 & Homogen \\
\hline
\end{tabular}


Kesimpulan yang diperoleh adalah kedua kelas yang digunakan dalam penelitian ini adalah data responden yang berasal dari populasi yang terdistribusi normal.

Tabel 3. Hasil Uji Homogenitas

\begin{tabular}{c|c|c|c|c|c|c|l|}
\multirow{2}{*}{ Perlakuan } & \multicolumn{2}{|c|}{ Nilai Lavene Statistic (pretest) } & \multicolumn{3}{c|}{ Nilai Sig. } & \multirow{2}{*}{ Kesimpulan } \\
\cline { 2 - 7 } & Puczle & Emosi & $\begin{array}{c}\text { Motorik } \\
\text { halus }\end{array}$ & Prezle & Emosi & $\begin{array}{c}\text { Motorik } \\
\text { Halus }\end{array}$ & \\
\hline Sebelum & 0.770 & 0.772 & 0.775 & 0.582 & 0.584 & 0.560 & Homogen \\
\hline Sesudah & 2.059 & 2.108 & 2.079 & 0.306 & 0.310 & 0.316 & Homogen \\
\hline
\end{tabular}

Kesimpulan yang diperoleh adalah kedua kelas yang digunakan dalam penelitian ini adalah data responden yang berasal dari populasi yang homogen.

Tabel 4. Hasil Uji Anava Dua Jalur

Tests of Between-Subjects Effects

\begin{tabular}{|c|c|c|c|c|c|c|}
\hline Source & $\begin{array}{c}\text { Type III Sum of } \\
\text { Squares }\end{array}$ & Df & Mean Square & $\mathrm{F}$ & Sig. & $\begin{array}{c}\text { Partial Eta } \\
\text { Squared }\end{array}$ \\
\hline Corrected Model & $3945.500^{\circ}$ & 5 & 789.100 & 3156.400 & .000 & 1.000 \\
\hline Intercept & 61716.050 & 1 & 61716.050 & 246864.200 & .000 & 1.000 \\
\hline sesudah & 3945.500 & 5 & 789.100 & 3156.400 & .000 & 1.000 \\
\hline Error & .500 & 2 & .250 & & & \\
\hline Total & 75388.000 & 8 & & & & \\
\hline Corrected Total & 3946.000 & 7 & & & & \\
\hline
\end{tabular}

a. $R$ Squared $=1,000$ (Adjusted $R$ Squared $=1,000$

Berdasarkan tabel uji anava dua jalur diatas, item Corrected Model mewakili pengaruh semua variabel independen yaitu variable permainan puzzle, secara bersamasama terhadap variabel dependen yaitu variabel perkembangan emosi dan kemampuan motorik halus. Hasil signifikasi (Sig.) diperoleh < 0,05 (Alfa) sama dengan signifikasi, yang artinya bahwa kedua variabel independen dan dua variabel dependen adalah valid.

Hipotesis (Ho) 1 : Tidak ada Pengaruh Permainan Puzzle terhadap Perkembangan Emosi Anak Usia Dini di Play Group Kecamatan Sumbersari Kabupaten Jember Semester Genap Tahun Ajaran 2018-2019 diketahui bahwa nilai Fhitung perkembangan emosi adalah sebesar 3584.375 dengan signifikasi 0.002, maka 
kriteria pengambilan keputusannya adalah Ho ditolak. Sehingga bisa disimpulkan bahwa ada pengaruh permainan puzzle terhadap perkembangan emosi anak usia dini di Play Group Kecamatan Sumbersari Kabupaten Jember Semester Genap Tahun Ajaran 2015-2016.

Hipotesis (Ho) 2 : Tidak ada Pengaruh Permainan Puzzle terhadap Kemampuan Motorik Halus Anak Usia Dini di Play Group Kecamatan Sumbersari Kabupaten Jember Semester Genap Tahun Ajaran 2018-2019 diketahui bahwa nilai Fhitung kemampuan motorik halus adalah sebesar 7045.500 dengan signifikasi 0.001, maka kriteria pengambilan keputusannya adalah Ho ditolak. Sehingga bisa disimpulkan bahwa ada pengaruh permainan puzzle terhadap kemampuan motorik halus anak usia dini di Play Group Kecamatan Sumbersari Kabupaten Jember Semester Genap Tahun Ajaran 2015-2016.

Hipotesis (Ho) 3 : Tidak ada Pengaruh Permainan Puzzle terhadap Perkembangan Emosi Anak dan Kemampuan Motorik Halus Secara Bersama-sama Usia Dini di Play Group Kecamatan Sumbersari Kabupaten Jember Semester Genap Tahun Ajaran 2018-2019 diketahui bahwa nilai F-hitung perkembangan emosi dan kemampuan motorik halus adalah sebesar 4532.375 dengan signifikasi 0.000, maka kriteria pengambilan keputusannya adalah Ho ditolak. Sehingga bisa disimpulkan bahwa ada pengaruh permainan puzzle terhadap perkembangan emosi dan kemampuan motorik halus anak usia dini di Play Group Kecamatan Sumbersari Kabupaten Jember Semester Genap Tahun Ajaran 2018-2019.

\section{KESIMPULAN DAN SARAN}

Berdasarkan data dan hasil analisis dalam penelitian dapat ditarik kesimpulan bahwa ada perbedaan perkembangan emosi dan kemampuan motorik halus ana sebelum melakukan permainan puzzle dengan perkembangan emosi dan kemampuan motorik halus anak sesudah melakukan permainan puzzle. Hal tersebut dapat dilihat dari nilai yang diperoleh awal sebelum melakukan permainan puzzle sebesar 123.742 mengalami peningkatan setelah melakukan permainan puzzle dengan nilai sebesar 173.942. sehingga dapa disimpulkan dengan adanya pengaruh permainan puzzle terhadao perkembangan emosi dan kemampuan motorik halus anak usia dini secara bersama-sama anak usia dini. Dari hasil penelitian dan kesimpulan tersebut, peneliti 
merekomendasikan bahwa permainan puzzle dapat meningkatkan perkembangan emosi dan kemampuan motorik halus anak usia dini. Untuk guru atau pendamping sebaiknya meluangkan waktu untuk dapat mengaplikasikan permainan puzzle tersebut ke dalam proses bermain baupun belajar anak usia dini.

\section{REFERENSI}

Abdurahman, M. 2011. Dasar-Dasar Metode Statistik Untuk Penelitian. Bandung: CV. Pustaka Setia.

Arikunto, Suharsimi. 2006. Prosedur Penelitian, Jakarta : PT. Rineka Cipta.

Arikunto, Suharsimi. 2009. Manajemen Penelitian, : PT. Rineka Cipta.

Baharuddin, 2009. Pendidikan dan Psikologi Perkembangan, Jogyakarta : Ar - Ruzz Media.

Catron, Carol.E dan Allen, J. 1999. Early Childhood Curicculum : A Creative Play Model, $2^{\text {nd }}$ Edition, New Jersey : Merill Publication.

Direktorat PAUD. 2004. Acuan Menu Pembelajaran pada Kelompok Bermain. Direktorat Pendidikan Anak Usia Dini, Jakarta : Direktorat PAUD.

Grafura, Lubias. 2011. Permainan Edukatif, Jakarta : Prestasi Pustaka Publisher.

Gordon, Ann, Miles, dan Browne, Kathryn Williams. 1999. Beginning dan Beyond: Foundations in Early Childhood Educations, New York : Delmars Publishing Inc.

Hamalik, Oemar. 1989. Media Pendidikan, Bandung : Citra Aditya Bakti

Hasan, I. 2002. Pokok-Pokok Materi Metodologi Penelitian dan Aplikasinya, Jakarta : Ghalia Indonesia.

Hidayah, Rifa. 2009. Psikologi Pengasuhan Anak. Malang : Sukses Offset.

Hurlock, Elizabeth B. 1978. Perkembangan Anak. Jakarta : Erlangga.

Margono, Gatot. 2014. Pembelajaran Berbasis Permainan Pada Pendidikan Anak Usia Dini Di PAUD Permataku Kota Palu, Malang.

Mutiah, Diana. 2012. Psikologi Bermain Anak Usia Dini, Jakarta : Kencana Prenada Media Group.

Morrison, George. S. 2012. Dasar-Dasar Pendidikan, Jakarta : PT. Indeks. 
Pengenalan Angka Menggunakan Permainan ... (Abristiana, Kristanti dan Aisyatul W.)

Padmenodewo, Soemiarti. 2003. Pendidikan anak Prasekolah. Jakarta: PT Asdi Mahasatya.

Pramono, Titin S. 2012. Permainan Asyik Bikin Anak Pintar, Yogyakarta : IN AzNa Books.

Putra, Nusa, 2012. Penelitian Kualitatif PAUD, Jakarta : PT. Raja Grafindo Persada.

Saleh, S. 2001. Statistik Induktif Edisi Revisi, Yogyakarta : Unit Penerbit dan Percetakan AMP YKPN.

Sunarto. 2006. Perkembangan Peserta Didik, Jakarta : Rineka Cipta.

Suryabrata, S. 2006. Metodologi Penelitian, Jakarta : PT. Raja Grafindo Persada.

Sora, 2015. Pengertian Populasi dan Sampel Serta Teknik Sampling, Maret.

Umar, Husein. 2008. Metode Penelitian Untuk Skripsi dan Tesis Bisnis Edisi Kedua, Jakarta : Pt. Raja Grafindo Persada.

Wardani, Dani. 2009. Bermain Sambil Belajar, Jakarta : Edukasia.

Yulianty, Rani. 2009. Model Pendidikan Anak Usia Dini, Jakarta : Kencana.

Yulianty, Rani. 2013. Permainan yang Meningkatkan Kecerdasan Anak, Jakarta : Niaga Swadaya. 